\title{
Import and Export of Small Cardamom in India
}

\author{
M.Anbuchelvi \\ Assistant Professor, Department of Economics \\ Cardamom Planters Assocition College, Bodinayakanur, Tamil Nadu, India
}

\section{OPEN ACCESS}

Volume: 7

Issue: 1

Month: July

Year: 2019

ISSN: 2321-788X

Received: 17.06.2019

\begin{abstract}
Indian Small Cardamom is famous in the world over decades for its' quality, colour and standards. However, India imports Cardamom from other countries for various reasons such as high price in the domestic market, bulk seasonal and festival demand for Cardamom from North India. Countries like Guatemala with a wide area of plantations with naturally conducive weather and climate paves the way for mass production of Cardamom at a lower cost. This has resulted in the mixing of those lesser quality cardamoms with higher quality Cardamom produce in India. Moreover, there are many illegal routes with which Guatemala Cardamom is smuggled into India.Export of Cardamom has several formalities and procedures to be followed. The State and Central Government have regulated the import and export of cardamom to various countries in the world. There are several distributing channels of Cardamom with auction centres, wholesaler, retailer and other intermediaries through which the Cardamom reaches the customers in India and abroad. The international market for Indian Cardamom is competitive as more countries try to dump their product. But there is ample scope for Indian Cardamom to rule in the Global Market.
\end{abstract}

Keywords: Import, Export of Cardamom and Foreign Earning for India.

\section{Introduction}

In the world, India has the most prominent domestic market for spices.

Accepted: 22.06.2019

Published: 01.07.2019

Citation:

Anbuchelvi, M. "Import and Export of Small Cardamom in India.” Shanlax International Journal of Arts, Science and Humanities, vol. 7 , no. 1,2019 , pp. $97-111$

DOI:

https://doi.org/10.34293/ sijash.v7i1.561

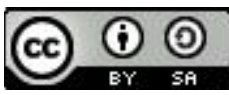

This work is licensed under a Creative Commons Attribution-ShareAlike 4.0 International License Spices have been grown in small land holdings, with organic farming gaining influence in recent times. "India is the world's largest country that is the producer, consumer and also the exporter of spices. It produces about 75 of the 109 varieties listed by the International Organization for Standardization (ISO) and accounts for half of the global trading in spices. ${ }^{1 "}$

Imports and exports are the two essential components of foreign trade. The exchange of goods and services between the two countries is called Foreign Trade, across their international borders.'Imports' imply the physical movement of goods into a country from another country in a legal way. It refers to the products that are produced abroad by foreign producers and are used in the domestic economy to cater to the needs of local consumers. Likewise 'exports' imply the physical movement of goods out of a country in a legal manner. It refers to the products that are produced domestically in a country and are used to cater to the needs of the consumers in foreign countries. Thus, imports and exports have made the world a local market. The land which is purchasing the goods is known as the importing country, and the country which is selling the products is known as the exporting country. The traders involved in such transactions are importers and exporters.

Exports are one component of international trade. The other part is imported. They are the goods and services bought by a country's residents that are produced in a foreign country. Combined, they make up a country's trade balance. When the country exports more than its imports, it has a trade surplus. When it imports more than it exports, it has a trade deficit.

1. www.ibef.org/exports/spice-industry-indias.aspx 
Spices from India, especially the Malabar coast of the olden times that is now called Kerala, had travelled to the Mediterranean, Mesopotamia, Persia, northern Africa (and where not!) through channels that could be compared to the celebrated Silk Route. All of them came here in search of the smell of life: Greeks, Romans, Babylonians, Egyptians, Chinese and the Arabs... Malabar spices had been salted of the precious life for the Arabs of antiquity and medieval times, and they continue to be so. Saudi Arabia remains the biggest importer of Kerala spices. The Old Testament, old literary works of Arabia and Persia are a testimony to the fame Indian spices had enjoyed the world over once upon a time. It was this mystery that put me on the road to Kerala's spice country, Idukki, where many spices grew on the same terrain. India has been able to sustain the demand for its trademark spices in international markets in the face of stiff competition and stringent food safety regulations that now define the global commodity trade.Small cardamom registered maximum export growth both in value and volume. "A total of 4,180 tonnes valued at Rs 456.01 crore was exported during the April-December 2017 period as against 2,910 tonnes Rs 297.80 crore in 2016. There are important studies related to the import and export of cardamom in India."

Economic Review (1982) published by the Government of Kerala, stated that the critical problem for the cardamom industry in India is the fierce competition it has to face in the international market, especially from Guatemala. Compared to the price level in 1978-79 there has been a decline of 35 per cent in export price in 1981-82 both for Kerala and all India, and this trend adversely affects the industry. Planting new varieties, avoidance of crop loss by improving the curing process, are some of the suggestions recommended in the report for bettering the prospects of cardamom ${ }^{3}$.

Swaminathan (1985) in his thesis on 'Trends in the area, production and export price of cardamom in Kerala, Tamilnadu and Karnataka' were made for a comparative study. The primary objective of projecting the probable future share of these states in the International Cardamom Market. The 2. Www.CommodityIndia.com

3. Economic Review. (1982). Thiruvananthapuram: Published by State Planning Board. researcher also studied the trends in the export price of cardamom and gave much importance to the regional comparison of cardamom production and the growth so that all other aspects of the field were left untouched ${ }^{4}$.

Baby Jacob (1985) in his thesis "Export development of Kerala", studied the export performance of Kerala, analysing the trends and problems and also made a comprehensive analysis of the then prevailing export policies of the Government. The production of cardamom, being major export items were evaluated well, and remedial solutions were recommended to the problems of significant export items, including cardamom ${ }^{5}$.

Muhammad Sajjad (1987) on 'India's Cardamom Trade with Middle East' clearly pointed out the changing pattern of India's cardamom trade with the Gulf countries'. With the support of the statistical data, the Economics of Cardamom cultivation and the prospects of the sector were discussed in detail. According to him, the high price of Indian cardamom was the reason for the decline of the volume of and the export competitive pricing strategy, which was the only solution to the problem ${ }^{6}$.

Gopalakrishnan Nair (1987) in his thesis, 'Problems and prospects of marketing cardamom in India and abroad', was outlined and the problems of marketing cardamom inside and outside the country were also taken care. The study has highlighted the future market possibilities abroad and suggested measures for increasing the export volume and enhancing the prospects of cardamom plantation in India and in abroad. He analysed the problems of production cardamom and made some crucial suggestions to solve such issues to a great extent ${ }^{7}$.

4. Swaminathan, S., Trends in the area, production and export price of cardamom in Kerala, Tamil Nadu and Karnataka, M.Phil Thesis, Madurai: Kamaraj University, 1985.

5. - Baby Jacob, "Export development of Kerala" PhD Thesis Cochin CUSAT 1985.

6. Muhammad Sajjad, A., India's Cardamom trade with Middle East Countries, M.B.A Project report, Calicut: University of Calicut, 1987.

7. Gopalakrishnan Nair, N., Problems and Prospects of Marketing Cardamom in India and Abroad, Unpublished $\mathrm{PhD}$ Thesis, Cochin: CUSAT, 1987. 
Meena Benjamin (1988) studied the problems and prospects of exports of value-added spices in general and spice oils and oleoresins in particular, in her project report named 'Problems and prospects of Export of Spices Oils and Oleoresins from India'. The study covered the processing of spices, oils, major market trends, export, problems, export incentives, review of the export volume of cardamom producing countries, and distribution problems of value-added spices. The study offered valuable indications to the future possibilities of spices related to processing and value additions ${ }^{8}$.

Ramesh (1990) in his thesis 'Volume of trade and its impact on the Economic Development of Kerala', made a comprehensive study of the role of trade in Kerala's economy, including the structure and composition of Kerala's foreign trade and the interstate commodity flows. Spices were the prominent export products, and hence, their trade significance was discussed in detail. This study pointed out the scope and potentials of the spices of Kerala and also highlighted the comparative advantages of spices over the other agricultural products of Kerala ${ }^{9}$.

Chacko Jose (1994) made "a study on production and export of cardamom in India". This study indicated that India was the world's largest producer of cardamom until (1979-80) and its position came down diminished in the subsequent years due to several factors. There had been occasional small hikes and frequent sharp slumps in production. The fluctuations in the production of cardamom the year was mainly attributed to the vagaries of nature. Due to the low production of cardamom, the exports have decreased. However, in 1990-91 and 1992-93, there had been a significant increase in trading ${ }^{10}$.

Mani and Chakojose (1997) conducted a study

8. Meena, Benjamin, Problems and Prospects of Exports of Spices Oils and Oleoresins from India, M.B.A. Project report, Calicut: University of Calicut, 1988.

9. Ramesh, B., Volume of trade and its impacts on the economic developmentsof Kerala, Unpublished $\mathrm{PhD}$ Thesis., Calicut: University of Calicut, 1990.

10. ChakoJose, P., (1994) "Production And Export of Cardamom In India" Yojana (1994), Vol 38, No 21 pp 16-21. on the export of cardamom statedthat the cardamom yield was low, and there were frequent fluctuations in the field during the study period. The study found that the trend in the export of cardamom has come down drastically due to the high cost of production, low quality and effective entry of Guatemala in this trade. The major problems faced in the Indian cardamom exports were low productivity, Taxes related issues, re-plantation problem, high rate of export duty per-shipment problems and limited storage facilities in the ship ${ }^{11}$.

John (2000) in his thesis "A study of the export trends of Kerala' evaluated the growth, commodity components and destination of export trade including spices. The researcher identified the current practices and practical problems of exporters in general and studied the trends in the export markets of cardamom. The study encompassed all the major items of exports from Kerala and depicted the declining export growth of Indian cardamom in the global market ${ }^{12}$.

Ganassamurthy.V.S and Manikam.S (2003) in this study an analysis of WTOand its impact on India's foreign Trade found that after WTO exports and imports and trade balance showed a declining trend to increase exports they suggested that Indian shipping should acquire a high degree of competitiveness by adopting new technology for international level ${ }^{13}$.

P.Hari Babu (2011) analysed the export performance of spices in India: an empirical study on Spices has been aprime source of lively hood for millions of people and above 3 million farmer sare engaged both directly orindirectly in spices cultivation, processing, manufacturing grading, marketing and other allied activities. So, the spices industry is a prominent place over the past seven decades. India is the world largest producer

11. Mani and Chakojose "Trends in the exports of cardamom problems and prospects" Agricultural Situation In India,1997 Vol 8 No 8 pp.106111.

12. John, K.C., "A study of the export trade of Kerala", Unpublished $\mathrm{PhD}$ Thesis, Thiruvananthapuram: University of Kerala, 2000.

13. Ganassamurthy. V.S. and Manickam.S., Made an analysis of WTO and its impact on India's foreign trade. Facts for you February 2003, pp. 31.33 
and exporter. The sustainability of Indian spices industry mainly depends on exports. India is now facing competition from many countries which are developing. The Indian spices processing industry have various problems like availability of raw material, un scientific production methods, Marketing problems etc. The world exports of spices fluctuated during the period understudy. Indian spices exports have more than doubled between 2008 to 2015. Thus many reasons can be attributed to the fluctuation of commodities during this period, such as an increase in food prices, inflation, world recession etc. The actual exports gained momentum after $2011^{14}$.

EttaMohanaRao and R.Sivaram Prasad (2018) in their analysis on "Production and Export Performance Indian Spices" attempted to observe the present state of Indian spices area of cultivation, production and exports and critically analyse the foreign exchange earnings through spices exports. For analysis spices area of cultivation, production and export data for ten years from 2007-08 to 2016-17 were collected, and Compound Annual Growth Rate tool isused to analyse the statistical data. During 2016-17 India spices cultivated area in 3535400 hectares and produced 7077300MT' sand out of it India has exported 947790MT's of spices and earned 17664.60 crores of foreign exchange. The largest producer and exporter of spices of the 109 varieties listed by the International Standard Organization (ISO) is India, as the country produced and exports about 75 types of spices in its climatic regions. Today Indian spices are the most soughtafter globally, given their exquisite aroma, texture and taste. India has the largest domestic market for spices in the world. India is the biggest trade partner of many prominent countries.

\section{The Methodology of the Study \\ Choice of the Topic and Area}

Export has assumed an essential place in the development of any country and considering it as the engine of Economic Growth. India requires a considerable amount of foreign exchange for its' critical import and for achieving rapid growth.

14. Parikalpana - KIIT Journal of Management, DOI:10.23862 / kiit- parikalpana/2017/v13/ i1/151275
Millions of job opportunities have to be created to utilise the youth for Nation building. Even though the country has different sources of foreign exchange, export earning is the safe way of obtaining it in the long run. Export of high valued traditional products not only gives foreign exchange but also employment to a large number of people. Spices are the traditional products of India, whose production process is highly intensive in semi and unskilled labour, and high domestic and foreign market prices compared to other conventional products. Idukki district in Kerala is the main centre for cardamom in Inia which is producing more than 20,000 metric tons in recent years. There is much scope for creating more quality Cardamom that is liked by exporters.

Stringent quality control measures established by the importing countries are also seen to have a dampening effect on prices in the long term. "The prices this week have gone up to Rs. One thousand two hundred levels, but we cannot expect more because of the insecticide ban by Saudi Arabia, a major consumer, on Indian cardamom consignment. ${ }^{15}$ "

\section{Statement of the Problem}

India is the largest producer, consumer and exporter of spices in the world. The production of cardamom in the world is estimated at 30,000 tones. Guatemala is the major producer with an annual output of 11,000 to 12,000 sounds. Indian Cardamom is superior in quality, but it has always been out-priced by Guatemala, where the domestic consumption is negligible. India is the second largest consumer of small cardamom after Saudi Arabia. The states of Kerala, Karnataka and Tamilnadu are the primary producers of small cardamom in India. Cardamom, which enjoys a dominant position in the international spices market. Kerala is the states which cultivate more than 50 percent of the area to be used for cardamom cultivation in India. In Kerala, Idukki district occupies a prominent position, as the whole region is geographically located in the most conducive place, which is highly suited for small cardamom plantation. Exportis a valuable source of income to the planters and Labourersinhabiting

15. V Sajeev Kumar, Vishwanath Kulkarni Kochi/ Bengaluru|Updated on August 21, 2018, Published on August 21, 2018. 
in Idukki District of Kerala. Thus, an analysis that is highlighting the internal problems and external barriers about import and export of cardamom in India over the decades becomes inevitable. This study will help the planters, marketers, intermediaries and policymakers to have a clear vision about the complicated business situation and necessary remedial changes to be made in the policy towards Cardamom Plantation and the marketing channels. There are so many risks, and uncertainties prevail in the present context of Cardamom production to delivery of consignment abroad. Though most of the dangers are unavoidable and beyond control, can be insured for the well-being of all concerned.

\section{Period of the Study}

Cardamom is a perennial crop which requires three to four years of gestation period during which there will not be any yield.It is a high-value product demanded by several countries all over the world. Hence, it is appropriate to take upa considerable periodto analyse the available data on import and export.The study covers 17 years from 2000-01 to 2016-17.

\section{Data Sources}

The primary data were collected from the Cardamom Planters, Labourers, District Authorities, wholesalers, retailers, exporters and customers using schedules prepared for the purpose. Secondary data were also collected from the publications of Spices Board, Cardamom Planters' Association, Cardamom Research Centre and also from the related web site on Cardamom. While the data on import and export are obtained over decades, the quantity was in metric tons with the value of the same in Indian Rupees. So appropriate statistical tools will bring meaningful estimation and results.

At last, the stakeholders, policymakers in the field of cardamom were also contacted, and the data and information were cross-checked before taken for an in-depth analysis. The data on the quantity in export and its' value in Indian rupees or US dollars are provided by many agencies, marketers and the respective Governments of the countries concerned. At this juncture, data were published by various sources of publications. The collected data and information on the International Cardamom business were cross-checked with other sources available about the selected period to have accuracy and reliability.

\section{Tools of Analysis}

The following instruments were employed to analyse the data concerning the objectives chosen for the study.

\section{Percentages}

Percentage differences in Cardamom production, price,import and export are to be worked out for comparison with the selected period. This gives a meaningful and straightforward comparison at a glance and paves the way for further statistical application with Computer Software.

\section{Mean, Standard Deviation and Co-efficient of Variation}

Mean, Standard Deviation and Co-efficient of Variation are to be calculated for the selected variables of the study such as Cardamom production, price, import and export of cardamom and its' foreign earnings. Fluctuations in the variables as mentioned above are to be carefully analysed with which some logical reasoning and corroboration of those selected variables will pave the way for a meaningful explanation.

\section{Trend and Compound Growth Rate}

Trend and compound growth rates are to be found for the selected variables such as import, the export of cardamom and foreign earnings of the Country. Since the Cardamom business is very peculiar. It is a perennial crop with a long gestation period, maintenance of the plants with ever increasing labour and fertiliser cost. Also, cumbersome marketing channels with variousnorms and regulations laid down by the Spices Board, affect Planters. The only way foranalysingsucha situationis possible with trend analysis and compound growth rates in percent.

\section{The Objectives are}

1. To identify and analyse significant factors influencing theProduction and Marketing of Cardamom about Import, Export and foreign 
earnings in India.

2. To analyse the problems encountered by the cardamom Planters in marketing, Import and Export of Cardamom in India.

3. To highlight the various risks and problems involved onthe part of the importer and exporter of Cardamom for the overall development of the Country.

4. To review the role played by the Spices Board of India and Government of India in the development of India's Export and Import policy on Spices.

5. To offer suitable policy suggestion for further the development of Cardamom Plantation with possible means of Import and Export policy changes for a favourable balance of trade in India.

\section{Limitation of the Study}

The study has a few limitations of time and resources. There are two types of cardamom cultivated in India, namely, small cardamom (Elettaria Cardamom Maton) and large cardamom (Amomum subulatumRoxburg). The present study covers the production, import and export of Small cardamom only. Although Small Cardamom is cultivated in three southern states of India, the area of the study is confined to the Idukki district of Kerala. This is because Kerala State alone accounts for 65 per cent of the total area under small cardamom cultivation and 75 per cent of the total production of cardamom in India. It is the most popular commercial variety of Indian cardamom, which is exclusively cultivated in Idukki, Kerala.

\section{Local Demand and Import}

Roughly 80 to 90 per cent of cardamom cultivated in Kerala is supplied domestically, due to the high demand from North India. To meet the local market, India even imports low-quality Guatemalan cardamom, which affects the price and standardisation of the Indian variant. Cardamom growers and traders said that the average prices touched a decade high of Rs 1,500 per $\mathrm{kg}$ this week from Rs 1,200 three months ago. Premium quality small cardamom is selling at an even higher rate of Rs 1,700 a kilogram. To quote, "the price of Cardamom raised to Rs. 4000, which is the highest on in the past 25 years, which is a result of plants affected by heavy rain earlier and drought in the corresponding next year. It is unfortunate to see minimal production and supply of Cardamom due to erratic climatic conditions ${ }^{16 "}$.

Due to the heavy rains, many cardamom plantations were destroyed. This resulted in a low yield. At the same time, both overseas and local demand increased and ultimately rose in prices of cardamom. In fact, "the traders and farmers are benefiting from import and export of cardamom. A significant part of the cardamom produced in India is consumed in the country itself. India also imports low-quality Guatemalan small cardamom to meet the demand ${ }^{17 "}$.

Cardamom produced in Guatemala costs half the Indian variant's price, and a large volume of it is imported to India. This makes its price fluctuate drastically. The mixing of Guatemalan cardamom and Indian cardamom has resulted in a decline in the latter's quality. There is an abundant inflow of cardamom stock as the auctions are conducted by Kerala cardamom processing marketing company. It strictly adheres to Export Quality standards. The importer should be well aware of market trends and market prices and have a proper assessment of the supply and demand position of Cardamom. The product is being sold mainly in auctions held at Vandanmedu, $28 \mathrm{~km}$ south of Kattappana, and Bodinayakanur in Tamil Nadu. And from there, it travels to ports abroad.

\section{Illegal Imports}

"If prices have not gone up, even more, considering the expectations of a 50 per cent output this year, it is because the Indian cardamom market was inundated during the second quarter (July to September) of fiscal 2016-17 by illegal cardamom from Guatemala. ${ }^{18 "}$ India imposes an import duty of 73 per cent on cardamom, and also insists on a minimum import price of Indian Rupees 500 per kilogram. Illegal import of Cardamom into the

\footnotetext{
16. The Dinamalar, Madurai Edition. Sunday, April 28th 2019.

17. N M Usman, senior field officer, development department, Spice Board India.

18. https://economictimes.indiatimes.com/
} 
Country hurts Indian Cardamom growers, who had already been affected by the fall in output with fluctuating prices. The present study tried to analyse the internal factors that influence the Cardamom production, import, domestic price, export price, export procedures and foreign earnings. The various risks on the part of the importer and exporter along with the policy measures and supportive schemes given by the Spices Board and the Government of India were also taken for analysis.

\section{Trends in Import of Small Cardamom}

There is no quantitative restrictionon import of cardamom in India as per the current Foreign Trade Policy.Duty-free imports areal so allowed under the Advance Authorization Scheme for value additionand re-export. There are many reasons for the import of cardamoms such as inadequate domestic supply, higher cost of Cardamom and the relatively lower price prevailing in certain countries. The following table presents the import of Cardamom into India for the period from 2000-01 to 2000-17.

Table 1 Import of Cardamom into India Quantity in Tonnes and Value (Rs. Lakhs)

\begin{tabular}{|c|c|c|}
\hline Year & $\begin{array}{c}\text { Import } \\
\text { (Qty in tones) }\end{array}$ & $\begin{array}{c}\text { Value } \\
\text { (Rs. in Lakhs) }\end{array}$ \\
\hline $2000-01$ & 380 & 1140.00 \\
\hline $2001-02$ & 383 & 1149.00 \\
\hline $2002-03$ & 410 & 1230.00 \\
\hline $2003-04$ & 390 & 1170.00 \\
\hline $2004-05$ & 420 & 1260.00 \\
\hline $2005-06$ & 437 & 1311.00 \\
\hline $2006-07$ & 623 & 1869.00 \\
\hline $2007-08$ & 875 & 2625.00 \\
\hline $2008-09$ & 180 & 540.00 \\
\hline $2009-10$ & 95 & 285.00 \\
\hline $2010-11$ & 769 & 2307.00 \\
\hline $2011-12$ & 817 & 2451.00 \\
\hline $2012-13$ & 956 & 2868.00 \\
\hline $2013-14$ & 1110 & 3165.00 \\
\hline $2014-15$ & 450 & 6574.95 \\
\hline $2015-16$ & 850 & 4474.05 \\
\hline $2016-17$ & 1720 & 8870.05 \\
\hline Average & 592.06 & 2331.71 \\
\hline S.D & 294.86 & 1717.66 \\
\hline
\end{tabular}

\begin{tabular}{|c|c|c|}
\hline C.V & 49.80 & 73.66 \\
\hline GCR & 5.49 & 10.32 \\
\hline
\end{tabular}

Source-Spices Board, 2017.

The quantity imported from Guatemala goes on increasing till 2007-08, and after that, it is declining and then rising. The decline noted during the period 2008-09, and 2009-10 is substantial when compared to earlier periods. Then the quantity of Import had increased steadily with some variations. One of the significant commercial risks is lack of knowledge on the part of the importer about the International market. Though the commercial risk is common in any business, the impact of it is more in International business. However, these risks may be minimised by using forecasting techniques and a careful watch on the ever-changing business conditions in India. Every country has its commercial laws. As a result, different laws prevail both in exporting and importing countries. In this situation, legal proceedings are complicated and very expensive. The trend using logarithm along with compound growth rate is estimated for the selected period of study to facilitate meaningful analysis of Import of cardamom into India (Quantity), which is shown in Table 2.

Table 2 Import Of Cardamom In India (Quantity): Its Estimated Trend

\begin{tabular}{|l|c|c|c|c|}
\hline Variable & B & SE B & t Value & Sig t \\
\hline Time & 0.053457 & 0.029809 & 1.793 & 0.0931 \\
\hline Constant & 5.745406 & 0.305451 & 18.810 & 0.0000 \\
\hline $\mathrm{R}^{\wedge}=0.18$ & d.f.15 & \multicolumn{3}{|c|}{$\mathrm{F}=3.22$} \\
& & Significance of ' $F$ ' $=0.000$ \\
\hline
\end{tabular}

Source: Computed Data.

The Regression coefficient alpha is positive and the value of which is 5.75. The Regression coefficient Beta is positive; the amount of Beta is 0.05 with an $\mathrm{F}$ value $3.22, \mathrm{R}$ square is 0.18 . The table shows that the linear regression has 17.7 per cent of the variance in the data. The Compound Growth Rate of Import is 5.49 per cent. There is a steady increase in the quantum of import of Cardamom with some variation. Since Cardamom is a perennial crop which is highly dependent on climatic conditions and shade management, naturally the production varies and as a result, all variables related also tend to fluctuate now and then. 


\section{Export of Small Cardamom}

Export performance is very much dependent upon cardamom production. Production for export requires quality and specifications according to international standards. Export pricing is very complicated and challenging. Export prices should be competitive in the global market. A foreign buyer looks for price and quality. The adaptability of the product in the overseas market plays an important role. Otherwise, the exporter will fail in exporting such a product.

Moreover, the International business is taking place in a faraway place and meeting the overseas buyer is a critical task. Due to longer transit time, if shipped by sea or delay in transit may result in the rejection of the goods. A good exporterunties these notes and succeed.

In the export of goods, the policy of the Government in each country is crucially important. Many Countries have cold war, and if a new government is elected, the previous administration may change, and as a result, the business becomes riskier on both parties. The Exporter should take insurance protection to cover the risks. The price of the export depends on the demand, competition, costs and the objectives of the exporting firms, regulations on pricing laws concerning price setting and Government regulations in both exporting and importing countries are taken into consideration.

India grew just over 20,000 tons of cardamom and exported around 4,700 tons in 2013-14. However, during 2015-16, 27,300 tons of cardamom was produced, and over 6,000 tonnes were shipped globally. In three years, production and exports have increased by 33.5 per cent and 30 per cent, respectively. "Indian spices have a particular liking globally. Though the country consumes a large portion of its production, it could cater well to the export market as well. India produces the superior quality of cardamom; hence, the Country has religious buyers across the globe. The trend will last in the future also. Guatemala is a prominent player, but they could not beat us in quality, ${ }^{19}$ " The Spices Board of India works for the development and worldwide promotion of Indian spices. It provides

19. Gulshan John, chairman, All India Spices Exporters Forum quality control, certification, registers exporters, documents trade information and provides inputs to the Central Government on policy matters. The board participates in major international fairs and food exhibitions to promote Indian spices, apart from organising various domestic events. This is the only board that supports and renders timely guidance and takes care of the welfare of Cardamom Planters in India.

\section{Overseas Economic Differences}

Another critical factor which makes the export marketing more complicated is the significant difference in the Economic levels of different Export Markets and the Standard of living in different countries. These differences in Economic level will inevitably require necessary marketing adjustments for success in overseas markets. The high-income developed countries are characterised by quality and service-conscious consumers. A more systematic and sophisticated marketing approach becomes essential for continued success in these markets.

Cardamom marketing paves the way for better national income and foreign exchange resulting in the overall development of the Economy. Marketing of spices is defined as the operations involved in the movement of food and raw materials from the planters to the final consumers . In India, there exists an elaborate and interconnected system of Cardamom markets through which the product flows from the Planters to the middlemen and the consumers ${ }^{20}$.

Spices' marketing has the most significant and most enduring role to play in Economic changes in developing countries like India. Marketing holds good for Spices development, which could determine the quality of urban life. An efficient internal marketing system for spice commodities holds the key for rural development and for meeting the challenges thrown up by explosive growth of population in developing countries.

\section{Global Cardamom Market}

Even though the country has different sources of foreign exchange, export earning is the safe way of obtaining it in the long run. Export of high valued

20. Lallan Singh, "Relationship between Apex and Primary Co-operative Marketing in Bihar", The Co-operator, Vol. XXII (9),1984, P.245 
traditional products not only gives foreign exchange but also employment to a large number of people. Spices are the traditional products of India, whose production process highly intensive in semi and unskilled labour, and high domestic and foreign market prices compared to other conventional products.However, "stringent quality control measures established by the importing countries are also seen to have a dampening effect on prices in the long term, sources in the Association of Planters of Kerala said. "The prices this week have gone up to 1,200 levels, but we cannot expect more because of the insecticide ban by Saudi Arabia, a major consumer, on Indian cardamom consignment."

\section{Spices Board in India}

Spices Board was constituted on 26th February 1986 under the Spices Board Act 1986 (No.10 of 1986) with the merger of the erstwhile Cardamom Board (1966) and the Spices Export Promotion Council (1960). Spices Board was one of the five Commodity Boards functioning under the Ministry of Commerce and Industry, Government of India. It is an autonomous body responsible for the export promotion of the scheduled spices and production and development of some of them such as cardamom and vanilla.

In the late fifties, Cardamom Research Stations were set up, one in Mudigere and another at Appangala by the Karnataka Agricultural University and one at Pampadumpara in Idukki District by the Kerala Agricultural University. The Cardamom Board was set up to look after the Research and Developmental activities of the cardamom (Small and Large).

As per the provisions of the Act, the Government of India formulates and announces an Export and Import policy (EXIM policy) and amends it from time to time. EXIM policy refers to the policy measures adopted by a country concerning its exports and imports. Such a system become particularly crucial in a country like India, where the import and export of items plays a vital role not just in balancing budgetary targets, but also in the overall economic development of the country. The principal objectives of the EXIM policy are:

- To facilitate sustained growth in exports of the country to achieve larger percentage share in the global merchandise trade.

- To provide domestic consumers with excellent quality goods and services at internationally competitive prices as well as creating a level playing field for the local producers.

- To stimulate sustained economic growth by providing access to essential raw materials, intermediates, components, consumables and capital goods required for augmenting production and catering services.

- To enhance the technological strength and efficiency of Indian agriculture, industry and services, thereby improving their competitiveness to meet the requirements of the global markets.

- To generate new employment opportunities and to encourage the attainment of internationally accepted standards of quality.

\section{Functions of the Spices Board}

Support for production, processing, domestic marketing and export of Cardamom.

\section{Administrative Functions}

- Development promotion and regulation of spices.

- Grant certificate of registration as an exporter of spices, issue license to cardamom auctioneers and dealers.

- Control quality of spices for export.

- Ensure remunerative returns to growers of Cardamom.

- Provide financial or other assistance for improved methods of cultivation and processing, replanting and extension of cardamom growing area.

- Regulate the sale of cardamom and stabilisation of the prices of cardamom

- Provide training in quality testing and fixing grading standards of cardamom.

\section{Various Schemes}

- Export Development Schemes.

- Adoption of High-Tech Processing.

- Trade Promotion and Technology Up gradation.

- Participation in International Meetings/Seminars/ Trade Fairs etc.

- Promotion of Indian Brands of Spice Products in Specified Markets.

- Product development and Research. 
With the support of the Spices Board, exporters had established adequate infrastructure for improving quality on a sustainable basis. Quality improvement and technological up gradation were the on-going programs. These developments were in tune with the changing levels of market acceptance. Other areas focused upon by the Board were an export promotion in identified markets, interaction with policymakers in the importing countries, development of new end uses, farm level training for farmers.

Export Inspection Council (EIC), New Delhi:The Export Inspection Council is responsible for the enforcement of quality control and compulsory preshipment inspection of various commodities meant for export and notified under the Export (Quality Control \& Inspection) Act, 1963.

Indian Institute of Foreign Trade (IIFT), New Delhi:- It trains the Personnel in modern techniques of international trade, Organisation of Research in problems of foreign trade;Organisation of marketing research, area surveys, commodity surveys, market surveys;Dissemination of information arising from its activities relating to research and market studies.

\section{Assistance for Export Production and Marketing}

Price and quality are essential in the international market and exemptions are granted to profits from export under the provisions of the income tax act. Export of poor quality of goods not only affects the reputation of the exporter but the image of the country, in foreign markets. The Spices Board was formed by the merging of Cardamom Board and the Spices Export Promotion Council. The headquarters is at Ernakulam, Kerala. It has a foreign office in Brussel. The Board is concerned with all the aspects of the spices industry, production and marketing for exports. It undertakes promotional campaigns such as advertisements, exhibition, and fairs.

"Farmers cannot tie up with exporters," because the planters need to go through middlemen who buy and aggregate the cardamom in mass. "They then give us the cardamom." Since the middlemen, who are individuals from across the border, cannot export owing to several documentations ${ }^{21}$.

21. http://www.kuenselonline.com/gst-impositionon-cardamom-export-to-india-affects-price/GST imposition on cardamom export to India affects price Nov 19, 2018.

\section{Shipment}

Shipping is a more popular method of dispatching goods to an export buyer than dispatcher by air. The freight charges for shipping cargo are very much less than those of air freight. The physical size of products sometimes constraints the exporter to dispatch them by air. A shipping bill is a primary document required by the customs authorities to grant permission for shipment. The Export Incentives are compensatory cash support, import replenishment license, Intellectual Property Rights (IPRs) Reimbursement, Duty Drawback and Excise Duty Refund.ExportProduction requires quality and specifications according to international standards. Design and packaging should be proper. Export pricing is very complicated and challenging. Export prices should be competitive in the global market.

Transportation of cargo has gone improvements over the decades. Most of the goods are transported by sea. Transit risks are a common hazard for International business. There are storms, collision, theft and explosion. The exporter should have thorough knowledge about marine insurance to get risk protection at a lower cost. It is always possible to transfer the financial losses due to perils of the sea. The principles of marine insurance are also applicable to air cargo.

\section{Organization for Export}

A separate department is in charge of export marketing. It is known as the Export Marketing Department. All export orders are received and executed through this department. It has to conduct promotion of goods, supply goods in different foreign markets, maintain liaison with international buyers, and so on. Export Formalities and financing various formalities have to be completed for exporting goods. Huge funds are required for all activities of export trade. Foreign exchange is required for undertaking export-related activities such as taking part in exhibitions abroad, international travel for promotion of exports. Export Finance has thus become an essential area of export management.

\section{Foreign Exchange Regulations Act, 1973 (FERA)}

Under FERA rules, it is obligatory that for all cash exports, the foreign exchange proceeds must 
be brought back to India within 180 days except where exports are made on a deferred payment basis. Foreign Exchange means it is the process of converting one National currency into another and of transferring money from one country to another.

The major importers are Saudi Arabia, Kuwait, UAE, USA, Japan, Pakistan, U.K, Malaysia, Israel, Australia, Canada, and South Africa. Saudi Arabia is the single largest importer of Cardamom in the world, followed by Kuwait. Cardamom oil is the essential ingredient in food preparations, perfumery, health foods medicines and beverages. Only 20 to 25 per cent of the production of small cardamom is exported to the middle-east market, mainly in Saudi Arabia. Middle East countries use cardamom for preparation of 'Gahwa' - strong cardamom - coffee concoction.

India consumes approximately 90 per cent of the domestic production with nearly 45 per cent of the demand coming from the western part of the country followed by northern India with 35 per cent. However, cheaper Guatemalan cardamom finds its way into the country and is preferred for low value uses like pan masala and bakeries. India exports 5 to 8 per cent of its total production, mostly the premium grade. India also exports by-products of cardamom such as cardamom oil and oleoresins to European countries. The essential traditional markets in West Asia and Far-East have been lukewarm since the mid 80's to Indian Cardamom Merchandise on account of price disadvantages over some time. Indian cardamom that ruled the Middle-east market in particular and the rest of the world in general for many years had all of a sudden faced the onslaught of stiff competition from Guatemala. Smart exporters in India should know about handling various risks, including commercial risks, political risks, credit risks, cargo risk and risk of variation of exchange rates.

\section{Trends in Export of Small Cardamom}

Indian cardamom is predominant in the world market with the competition from Guatemala which has emerged as a competitor for Indian Cardamom. It is also seen that export performance is very much dependent upon its production. Therefore, the correlation between the competition and the output can be established. India's output can stand the game in the world market.

To establish the functional relationship value and quantity of the exports of spices, here fitted a linear function $\mathrm{Y}$ (amount of species) $=\mathrm{A}+\mathrm{B}$ (Quantity of spices). To assess the trend of the export performance of spices, the average growth of Quantity in spices in tones and the average growth value of spices in rupees are to be taken as variables. Initially, before establishing their relationship between the cost and Quantity of spices, let us find out the normality of two variables to apply a parametric or a non-parametric correlation tool. The theory states that both the variables in correlation should be normally distributed. If anyone of them is not normally distributed the Karl-Pearson correlation is not appropriate (Gerrish \& Lathlean, 2015). So, it is better to apply the nonparametric test of a relationship, i.e., Spearman rank correlation for better results. It is observed that both the Spearman's rho and Kendall's tau are the best tools for examining the coefficient of relationship in the absence of normality in the analysing data. They best suit when the data is ordinal (Snyder \& Mangrum, 2005). The information has tested the normality of two variables using the Shapiro-Wilks test. The following table presents the export of Cardamom from India with quantity in tones and value in lakhs of rupees.

Table 4 Export of Cardamom (Small) From India (Quantity in Tonnes Values in Rupees in Lakhs

\begin{tabular}{|c|c|c|}
\hline Years & Quantity & Value \\
\hline $2000-01$ & 890.00 & 2872.2 \\
\hline $2001-02$ & 587.00 & 2487.00 \\
\hline $2002-03$ & 681.00 & 4707.40 \\
\hline $2003-04$ & 756.00 & 3691.70 \\
\hline $2004-05$ & 642.00 & 2362.40 \\
\hline $2005-06$ & 863.70 & 2682.10 \\
\hline $2006-07$ & 655.30 & 2348.10 \\
\hline $2007-08$ & 500.00 & 2475.00 \\
\hline $2008-09$ & 750.00 & 4726.50 \\
\hline $2009-10$ & 1975.00 & 16750.14 \\
\hline $2010-11$ & 1175.00 & 13216.66 \\
\hline $2011-12$ & 4650.00 & 25871.40 \\
\hline $2012-13$ & 2372.00 & 21215.04 \\
\hline $2013-14$ & 3600.00 & 28380.88 \\
\hline
\end{tabular}


International Journal of Arts, Science and Humanities

\begin{tabular}{|c|c|c|}
\hline $2014-15$ & 3795.00 & 32346.75 \\
\hline $2015-16$ & 5500.00 & 44982.75 \\
\hline $2016-17$ & 3850.00 & 42150.25 \\
\hline Average & 2087.76 & 15345.84 \\
\hline SD & 1901.07 & 15850.54 \\
\hline CV & 91.06 & 103.29 \\
\hline GCR & 16.41 & 23.40 \\
\hline
\end{tabular}

Source: Spices Board and statistics Division of Spices Board, Cochin 2017, Vol.v. p.38.

Since independence, the export of cardamom from India contributed significantly to earning over decades. The volume of trading in 2000-01 was 890 tones, and it reached a maximum of 3850 tons in 2016 17. Correspondingly the value of export cardamom in the year 2000-01 was Rs. 2872.2 Lakhs and the same increased to Rs.42,150 Lakhs in 2016-17. While the average export of cardamom was 2087 tones and the average value of it was 15345 Lakhs. The compound growth rate for the quantity of cardamom exported was and for its value were 16.41 and 23.4 per cent, respectively.The export of Cardamom from India has steadily increased with some fluctuations during the selected period. The Quantity of Export is encouraging to have more scope in the years to come. Therefore the present study is an attempt to analyse the various factors involved in Production, Import and Export and cardamom during 2000- 2017. The following table presents the estimated results.

Table 5 Export of Cardamom in India (Quantity): Its Estimated Trend

\begin{tabular}{|l|c|c|c|c|}
\hline Variable & B & SE B & t-Value & Sig. \\
\hline Time & 0.151938 & 0.022485 & 6.757 & 0.0000 \\
\hline Constant & 5.897001 & 0.230400 & 25.595 & 0.0000 \\
\hline $\begin{array}{c}\mathrm{R}^{\wedge}= \\
0.75\end{array}$ & d.f.15 & \multicolumn{3}{|c|}{$\mathrm{F}=45.66$ Significance of ' $\mathrm{F}$ ' } \\
$=0.000$ \\
\hline
\end{tabular}

The Regression coefficient alpha is positive and the value of which is 5.89. The Regression co-efficient Beta is positive; the amount of Beta is 0.15 with an $F$ value 45.66 , $R$ square is 0.75 . The table shows that the linear regression has 75 per cent of the variance in the data. Here it is seen that it is statistically significant. The Compound Growth Rate of Export is 16.41 per cent for the period."Cardamom, the queen of spices, is inching up to regain its lost position in international trade fetching more value and volume

\section{Share of Cardamom Export to Production in India}

The following table reveals the proportion of cardamom export from India to cardamom production in India for the period from 2000-01 to 2016-17.

Table 6 Proportion Of Cardamom Export To Production (Quantity in tones)

\begin{tabular}{|c|c|c|c|}
\hline Year & Production & Export & $\begin{array}{c}\text { Percentage } \\
\text { Share }\end{array}$ \\
\hline $2000-01$ & 10480 & 890.00 & 8.5 \\
\hline $2001-02$ & 11365 & 587.00 & 5.2 \\
\hline $2002-03$ & 11920 & 681.00 & 5.7 \\
\hline $2003-04$ & 11580 & 756.00 & 6.5 \\
\hline $2004-05$ & 16900 & 642.00 & 3.8 \\
\hline $2005-06$ & 17800 & 863.00 & 4.8 \\
\hline $2006-07$ & 15700 & 655.00 & 4.2 \\
\hline $2007-08$ & 13400 & 500.00 & 3.7 \\
\hline $2008-09$ & 15450 & 750.00 & 4.9 \\
\hline $2009-10$ & 15720 & 1975.00 & 12.6 \\
\hline $2010-11$ & 16000 & 1175.00 & 7.3 \\
\hline $2011-12$ & 15800 & 4650.00 & 29.4 \\
\hline $2012-13$ & 18400 & 1826.39 & 9.9 \\
\hline $2013-14$ & 21280 & 3600.00 & 16.9 \\
\hline $2014-15$ & 21800 & 4026.00 & 18.5 \\
\hline $2015-16$ & 22000 & 5500.00 & 25.0 \\
\hline $2016-17$ & 22300 & 3850.00 & 17.3 \\
\hline Average & 16346.76 & 1936.85 & -------- \\
\hline S.D. & 3876.06 & 1682.22 & -------- \\
\hline C.V. & 23.71 & 86.85 & -------- \\
\hline GCR & 4.38 & 15.17 & ------- \\
\hline
\end{tabular}

Source: Spices Board, 2017.

The table shows that the quantity exported forms

22. Dr A. Jayathilak, Chairman, and Spices Board. 
only a small portion of the total production of the country. This is on account of the high price of Indian cardamom due to the high cost of production as well as top domestic consumption of the spices in the country. From the stochastic modelling of the time series of total earning of cardamom from 2000-2001 to 2016-17 by India follows a polynomial function with the goodness of fit, i.e. R2 value 0.8606 . The direction of winning from cardamom by India had shown a stable export till 2007-08. The increases in the global market price, international demand and supply have increased the earning.

To sum up, the various issues discussed on the import of Cardamom into India are to be seriously viewed, and the Government of India should take care of controlling illegal activities and smuggling of Cardamom. Moreover, there should be clear policy directions about the setting of the price of Cardamom in Indian markets. The authorities in India should not leave it to chances and allow unwanted changes that happen in the Cardamom markets, which in turn affect the planter, marketers, go-betweens and ultimately the consumers. About the export of Cardamom, the Spices Board and the Government of India should support the planters against various types of risks faced by the ranchers and exporters. There are many formalities and procedures to be followed by the farmers and exporters inside the Country as well as overcomeother external factorsthathinder the export from the importing country. Nowadays, there are so many cultural, religious and political confrontations that prevail among different Nations that result ina fight with the development of International Trade. The Government of India should take steps to make the planters aware of issues in the Global market.

\section{Conclusion}

The growing of Cardamom which is a high-value product, at an altitude of 2,500 to 5,000 feet above sea level with cold climate and on the slope of the western Ghats pose a lot of problems and threats to the planters, labourers, marketers, and the consumers in India. Cardamom plantation is in the doll drums as the real business situation has become complicated and unsustainable. Planters struggle to survive in the hills to meet the ever-increasing cost of production, especially the labour and fertiliser cost. Also, there are new diseases and pest attack that challenge the day to day survival of the cardamom plantations and its' future.

The absence of rainfall at one season and followed by floods in the next season, shock the planters with enormous damage of crops and drop in yield which result in low productivity. These situations force the farmers to go for rooting out the old and damaged plants and substituting them with new large breed varieties that a Himalayan task at this juncture. There exist risks and uncertainties in every stage with which the planters grow the plants with a shortage of funds, non-availability of labour and limited credit facilities available.The farmers shoulder the burden and try to withstand and look fora favourable business over painful productioncondition.

Revamping the existing procedures followed from production to marketing, price fixing and levying of taxes should be modified in such a way to protect planter from the field to the product market. Even now, with the advancement of Online trading of Cardamom through Auction Centers, which eliminates so many intermediaries and various commissions, planters are not getting remunerative prices for their products. There are many reasons, such as a higher number of farmers have small size holdings, and indebtedness is a significant problem. When an unfavourable business condition exists, the only way to get rid of it is going for insurance. It is unfortunate to note that most of the planters are not aware of the various insurance schemes available. Only very few farmers make use of the insurance policy with a minimum sum assured. It is important to note that there is a shortage of supply of Cardamom due to non-availability of labour for harvest.

An exporter of cardamom should know the foreign market about selling off his export product. Taste and preferences of end users of the product play a vital role in any business market, especially in export-import trade.Most of the financial risks are not predictable. The changes in the international market are hazardous and difficult to anticipate. Suitability and acceptability of the product in the global market is rather difficult to gauge. Variations in supply and demand conditions are more unpredictable as a result; the traditional cardamom industry suffers for survival. 
Exporters cannot shift these risks to the professional risk's bearers, paying the insurance premium. The exporter is not informed of the conditions in the foreign market as the way he is aware of domestic demand. Long distances to travel along with time and cost implication distinguish international trade form local trade. In the Cardamom market, both at the national and international level, presence of competitors influences the demand and supply conditions, and entry of new competitors depresses the market more. Further, local production may bring down prices.

Many countries have a cold war with another state, either with neighbouring country or with other countries. It affects the trade relationship due to substantial risk in the trade.Up to some extent, political risks can be minimised by updating the status of dealing country's day to day movements through communication. The political dangers under export and import trade also can be avoided by proper selection of the countries to which goods are exported or imported. The primary threat is that most of the insurance companies do not cover political risks. However, those insurance companies which include political risks charge a high premium of insurance.

To prevent loss in a variation of the exchange rate is to enter an overseas business contract to pay the amount in local currency. Your buyer/importer buys - converts - your domestic currency and remits the amount to you in your local currency. The arrangements should be made well in advance before entering into the business contract.

Thus, it is revealed that there is much scope to undertake further research in the Economic, Social and Political context concerned with the Cardamom Plantation Industry in India. To mention, the everincreasing cost of production, drift in local and export prices, loss of supply due to non-availability of labour, problems in implementing various insurance schemes for the protection of plants and planters towards multiple risks involved in the process of production of Cardamom. There are more avenues of research analysis in the areas of marketing, import, export and foreign earning in the Cardamom Business at the Global level.

\section{References}

Basu, PK. "Foreign Trade Policy in India Since the Plan Period (1951-85)." Finance India, vol. XII, no. 4, 1998.

Burns. "Rules of Thumb for Correlation Strength.", Burns, Marketing Research, Pearson Education, India. 2007, pp. 541-542.

Chako Jose, P. "Production and Export of Cardamom in India." Yojana, vol. 38, no. 21, 1994. pp. 1621.

Dinamalar, Madurai Edition. Sunday, April 28th 2019.

Economic Review. State Planning Board, 1982.

Ganassamurthy, VS and Manickam, S. "Made an Analysis of WTO and its Impact on India's Foreign Trade." Facts for you, 1982, pp. 31-33. Gupta, AP. "Marketing of Agriculture Produce in India." Vora Publication Pvt Ltd, p. 1.

Mani and Chakojose "Trends in the Exports of Cardamom Problems and Prospects." Agricultural Situation in India, vol. 8, no. 8, 1997, pp. 106-111

Sanjeev, A. et al. Seed Spices, Quality and Export, Pointer Publishers, 2001.

Swaminathan, S. Trends in the Area, Production and Export Price of Cardamom in Kerala, Tamil Nadu and Karnataka. Madurai Kamaraj University, 2001.

Thakamani, CK. Organic Spices. New India Publishing Agency, 2009.

Vigneswara, Varmudy. Marketing of Spices. Daya Publishing House, 2001.

Lallan Singh, "Relationship between Apex and Primary Co-operative Marketing in Bihar", The Co-operator, vol. 22, no. 9, 1984, P.245.

Pal, S. "Agriculture Exports of India, Issues of Growth and Instability." Indian Journal of Agriculture Economics, 1992.

Peter, KV et al. "Spices Production and Export from India, Scenario through Five Decades." Advances in Spices Research, 2005, pp. 4350.

Abraham, D. Now Better with Cardamom. Cardamom Board Kochi, 1955.

Andre, Leu. Organic Farming and Climate Change. Spice India, 2010.

ASCI. Economics of Cardamom Cultivation of Small Growers. 1988. 
Behera, S and Indira, M. Indian Spices Challenges Ahead. 2010.

CBI. Spices and Herbs'. Netherlands: A Survey of the Netherlands and Other Major Markets in the European Union. 1999.

Chembakam et al. Processing and Value Addition in Spices, National Symposium on Spices and Aromatic Crops. Orissa University of Agriculture, 2007.

Common wealth Secretariat. Report of the 3rd Meeting of the International Spices Group. Food Production and Rural Development Division, 1991.

Common wealth Secretariat Reports. The Global Spice Trade and Uruguay Round Agreements. CWS, 1996.

Eapen, George. Strategies for Developing Export of Spices to the Wana Region. Proceedings of Workshop, 1989.

Financial Express. Cardamom Exports Decline Sharply, 2009.

Gulshan John, chairman, All India Spices Exporters Forum. 2009.

Indian Institute of foreign trade. Base Line Survey of Major spices in Kerala. The International Trade Centre, 1989.

Meena, Benjamin, Problems and Prospects of Exports of Spices Oils and Oleoresins from India. University of Calicut, 1988.

Muhammad Sajjad, A, India's Cardamom Trade with Middle East Countries. University of Calicut, 1987.
Anitha, PR. Trends Analysis of Spices Export at Cochin Port Trust. CUSAT, 2004.

Baby, Jacob. A Blue Print for Export Development of Kerala, A Study on Selected Agricultural Products. CUSAT, 1985.

Gopalakrishnan Nair, N. Problems and Prospects of Marketing Cardamom in India and Abroad. CUSAT, 1987.

Ibrahim, YC. Export Performance of Indian Spices in the WTO Regime. A Study with Special Reference to Pepper. CUSAT, 2007.

John, KC. A Study of the Export Trade of Kerala. University of Kerala, 2000.

Manju, Rajan. India's Spices Exports with Special Reference to Cardamom. CUSAT, 2004.

Ramesh, B. Volume of Trade and its Impacts on the Economic Developments of Kerala. University of Calicut, 1990.

Santhosh, P. Cost of Cultivation and Marketing of Pepper in Kannur Districts. Kerala Agricultural University, 1984.

Sherly, PG. Emerging Trends in Spices Exports, CUSAT, 2001.

Sindhu, M. Trade Liberalization and Export Performance of Kerala, CUSAT, 2001.

Thomas, TP. Problems and Prospects of Spices Trade in Kerala, M G University, 2009.

www.ibef.org/exports/spice-industry-indias.aspx www.CommodityIndia.com www.economictimes.indiatimes.com/ www.expressindia.com

\section{Author Details}

M.Anbuchelvi, Assistant Professor, Department of Economics, Cardam Planters Association College, Bodinayakanur, Tamil Nadu, India. Email ID: princedhanaraj@gmail.com. 